\title{
PECTIN SUBSTANCES OF SUGAR BEET PULP
}

\author{
N. P. Yuldasheva, M. A. Khodzhaeva, M. T. Turakhozhaev, \\ and Zh. Nurmukhamedova
}

UDC 547.917

In the Republic of Uzbekistan at the present time a plant for the production of apple pectin is operating at the Gazalkent preserving factory. With the aim of broadening the sources of pectin from local raw material, we have studied the pectin substances of beet pulp.

In contrast to the pectin of apple and lemon residues, the pectin substances (PcSs) of beet pulp have strong bonds with proteins, cellulose, lignin, and other structural elements of the cell wall [1]. In view of this, after the extraction of sucrose, sugar beet was subjected to hydrolysis with comparatively strong solutions of mineral acids $\left(\mathrm{HCl}, \mathrm{HNO}_{3}\right)$ and oxalic acid.

Below we give the results of the hydrolysis-extraction of beet pulp at a liquor ratio of 1:12 and the yields of PcSs:

$\begin{array}{lcccc}\text { Extractant } & \text { Time, } \mathrm{h} & \begin{array}{c}\text { Temperature, } \\ { }^{\circ} \mathrm{C}\end{array} & \begin{array}{c}\text { Yield of PcSs } \\ \%\end{array} & \text { Ash content, \% } \\ 0.2 \% \mathrm{HCl} \text { (A) } & 1.5 & 70 & 16.8 & 0.8 \\ 0.4 \% \mathrm{HCl} \text { (B) } & 3.0 & 85 & 23.6 & 2.1 \\ 2.0 \% \mathrm{HNO}^{2} \text { (C) } & 1.0 & 70 & 6.8 & 1.6 \\ 0.5 \% \mathrm{H}_{2} \mathrm{C} 2 \mathrm{O} 4 \text { (D) } & 2.0 & 70 & 5.49 & 3.0\end{array}$

A high yield of pectin with a low ash content was obtained on hydrolysis-extraction with $0.2-0.4 \% \mathrm{HCl}$. All the PcSs isolated consisted of light cream-colored powders.

The physicochemical parameters of the pectin substances obtained with different extractants differed to some degree:

\begin{tabular}{c|c|c|c|c|c}
\hline $\begin{array}{l}\text { Pectin } \\
\text { substances, }\end{array}$ & $\begin{array}{c}\text { Degree of } \\
\text { esterification }\end{array}$ & $\mathrm{C}_{\mathrm{O}}, \%$ & $\mathrm{C}_{\mathrm{M}}, \%$ & GalUA, \% & OAc, \% \\
\hline A & 55.2 & 9.6 & 7.8 & 63.94 & 3.44 \\
B & 67.0 & 10.3 & 6.6 & 64.66 & 1.61 \\
C & 42.8 & 7.5 & 10.6 & 63.70 & 2.4 \\
D & 97.0 & 8.2 & 4.8 & 52.3 & 3.86
\end{tabular}

The pectin substances of the beet extracted by solutions of hydrochloric and nitric acids were more highly methoxylated than those extracted by oxalic acid. The galacturonic acid contents of the PcSs scarcely differed, with the exception of the PcSs extracted by the $\mathrm{H}_{2} \mathrm{C}_{2} \mathrm{O}_{4}$ solution. All the beet PcSs contained acetyl groups and a predominating amount of carboxy groups, in contrast to apple and citrus pectins. These factors were responsible for the low gelling power of the beet pectin and for its capacity for sorbing heavy-metal ions.

The monosaccharide compositions of all the PcSs were identical, as could be seen from an analysis of their hydrolysates ( $2 \mathrm{~N} \mathrm{H}_{2} \mathrm{SO}_{4}, 48 \mathrm{~h}$ ). In all the hydrolysates, $\mathrm{PC}$ (butanol-pyridine - water (6:4:3)) revealed the presence of galacturonic acid, arabinose, xylose, rhamnose, and traces of glucose, which is characteristic for the class of pectin substances. After the extraction of the PcSs, we extracted hemicellulose (HMC) with a $10 \%$ caustic soda solution. The yield of polysaccharide was 2.21\%. GalUA, Ara, Gal, Xyl, and Rha were detected in a hydrolysate by PC.

Thus, pectin substances and hemicellulose have been extracted from the pulp of local varieties of sugar beet. A physicochemical characterization of the PcSs has been made, and the monosaccharide compositions of the beet pectin and hemicellulose have been determined.

\section{REFERENCE}

1. G. B. Aimukhamedov, D. É. Alieva, and N. P. Shelukhina, The Properties and Use of Pectin Substances [in Russian], Ilim, Frunze (1984), p. 64.

Institute of the Chemistry of Plant Substances, Academy of Sciences of the Republic of Uzbekistan, Tashkent, FAX (3712) 8914 75. Translated from Khimiya Prirodnykh Soedinenii, No. 4, pp. 562-563, July-August, 1994. Original article submitted December 6, 1993. 